\title{
Surfactant Treatment at Birth Reduces Lung Vascular Injury and Edema in Preterm Lambs
}

\author{
DAVID P. CARLTON, SOO CHUL CHO, PENNY DAVIS, MENNO LONT, AND \\ RICHARD D. BLAND
}

Children's Research Center, Department of Pediatrics, University of Utah, Salt Lake City, Utah 84132

[D.P.C., P.D., M.L., R.D.B.], and Department of Pediatrics, Chonbuk National University Medical School,

Chonju, Korea 560-182 [S.C.C.]

\section{ABSTRACT}

To study the effect of surfactant administration on fluid balance in the premature lung, we measured pulmonary vascular pressures, lung lymph and pleural liquid flow, and concentrations of protein in lymph, pleural liquid, and plasma before and after birth in 12 chronically catheterized preterm lambs (127-128 d gestation) treated with either placebo or surfactant just before surgical delivery. Eight lambs received intrapulmonary saline (placebo), and four lambs received surfactant; all lambs were mechanically ventilated with $\mathrm{O}_{2}$ for $8 \mathrm{~h}$ after birth. In control lambs, lung lymph and pleural liquid flow increased from $2.7 \pm$ $0.4 \mathrm{~mL} / \mathrm{h}$ during the $2-4 \mathrm{~h}$ before birth to $9.2 \pm 2.1 \mathrm{~mL} / \mathrm{h}$ by $6-8$ $\mathrm{h}$ after birth; lymph and pleural space protein drainage increased from $58 \pm 7 \mathrm{mg} / \mathrm{h}$ during the $2-4 \mathrm{~h}$ before birth to $134 \pm 25$ $\mathrm{mg} / \mathrm{h}$ by $6-8 \mathrm{~h}$ after birth. In lambs treated with surfactant, there was no significant increase in lymph and pleural liquid flow after

Pulmonary edema is an important pathologic feature of the respiratory failure that frequently follows premature birth (13). Excess lung water and atelectasis from surfactant deficiency interfere with pulmonary mechanics and respiratory gas exchange, often resulting in the need for mechanical ventilation with supplemental oxygen.

Treatment with surfactant after premature birth usually, but not invariably, lessens respiratory distress (4). Systemic oxygenation improves immediately after surfactant administration, and typically there is progressive improvement of lung mechanics and gas exchange for several hours thereafter $(5,6)$. The cause for this gradual pulmonary improvement is unclear, but it may reflect changes in postnatal lung fluid balance.

Theoretically, surfactant replacement should improve lung fluid balance after premature birth by reducing transvascular filtration pressure $(7,8)$. Consistent with this notion, laboratory studies in surfactant-deficient isolated lungs from preterm fetal rabbits showed that alveolar liquid pressure increases after

Received August 19, 1994; accepted November 11, 1994.

Correspondence: David P. Carlton, M.D., Department of Pediatrics, University of Utah School of Medicine, 50 North Medical Dr., Salt Lake City, UT 84132.

Supported in part by National Heart, Lung, and Blood Institute Grants HL-25816 and HL/HD-40802. birth (before birth, $2.3 \pm 0.3 \mathrm{~mL} / \mathrm{h} ; 6-8 \mathrm{~h}$ after birth, $3.4 \pm 0.9$ $\mathrm{mL} / \mathrm{h})$; likewise, lymph and pleural space protein drainage did not change after birth (before birth, $54 \pm 6 \mathrm{mg} / \mathrm{h} ; 6-8 \mathrm{~h}$ after birth, $50 \pm 8 \mathrm{mg} / \mathrm{h}$ ). Postmortem extravascular lung water was significantly less in lambs treated with surfactant compared with control lambs (control, $6.5 \pm 0.3 \mathrm{~g} / \mathrm{g}$ dry lung; surfactant-treated, $5.0 \pm 0.2 \mathrm{~g} / \mathrm{g}$ dry lung). Thus, surfactant administration at birth diminishes transvascular movement of fluid across the pulmonary microcirculation, preserves lung vascular protein permeability, and reduces pulmonary edema in newborn lambs that are delivered prematurely. (Pediatr Res 37: 265-270, 1995)

Abbreviations
$\mathbf{L} / \mathbf{P}$, concentration of protein in lymph relative to that in
plasma

surfactant replacement, a finding that might be expected to reduce fluid movement from the pulmonary microcirculation into the interstitium (9).

These theoretical and experimental considerations aside, previous studies have not shown a decrease in extravascular water content of lungs from premature animals that were treated with surfactant at birth $(10-12)$. It is possible that the duration of these studies was not sufficient to permit detection of changes in postnatal lung water content, which is influenced both by time-dependent clearance of fetal lung liquid and by the rate of liquid filtration from the pulmonary microcirculation into the interstitium. Moreover, the pulmonary edema that is often associated with respiratory distress after premature birth at least partly derives from abnormal lung vascular permeability (1), which may be unaffected by surfactant replacement. Thus, despite a reduction in transvascular filtration pressure after surfactant treatment (9), excess fetal lung liquid may be retained within terminal respiratory units, and more fluid may enter the interstitium from the circulation.

The purpose of this study was to see whether surfactant treatment at the time of delivery might decrease lung vascular protein permeability and edema after premature birth. Because clearance of fetal lung liquid and alterations in lung vascular 
permeability after birth occur over several hours $(1,13)$, we studied net transvascular movement of fluid and protein for 8 $\mathrm{h}$ after birth in preterm lambs that were prepared with chronic lung lymph fistulas and that received surfactant or placebo at the time of delivery. In lambs that did not receive surfactant, liquid and protein flow from the lung lymphatics and pleural spaces was two to four times greater $6-8 \mathrm{~h}$ after birth than before birth; treatment with surfactant at birth inhibited these changes and reduced extravascular lung water.

\section{METHODS}

Surgical preparation. By methods previously described (1), we surgically prepared 12 mixed-breed fetal lambs at 121-125 $\mathrm{d}$ gestation (term, $147 \mathrm{~d}$ gestation) to measure systemic and pulmonary vascular pressures and lung lymph and pleural liquid drainage. After giving 1\% halothane inhalation anesthesia to the ewe, we performed a midline hysterotomy and placed catheters in the abdominal aorta and inferior vena cava of the fetus through an incision in a hindlimb. We then performed a right thoracotomy to place catheters in the pleural space and efferent duct of the caudal mediastinal lymph node, which in lambs receives half to two thirds of total lung lymph (14). We ligated the tail of the node to eliminate nonpulmonary sources of lymph (15). A small segment of the lymphatic catheter (1-2 $\mathrm{cm}$ length, $0.28 \mathrm{~mm}$ inside diameter, $0.61 \mathrm{~mm}$ outside diameter) was inserted inside the efferent duct and then attached to a longer segment of catheter $(80 \mathrm{~cm}$ length, $0.76 \mathrm{~mm}$ inside diameter, $1.27 \mathrm{~mm}$ outside diameter) outside the duct. The interior of the lymphatic catheter was treated with heparin to prevent clotting (TDMAC processing, Polysciences, Inc., Warrington, PA). We performed a left thoracotomy to place catheters in the pulmonary artery, left atrium, and pleural space. A catheter for measurement of amniotic pressure was secured to the chest of the lamb. All catheters were brought through the uterine incision and exteriorized through the ewe's flank. After surgery, the ewe and fetus received antibiotics daily. The study was approved by the Committee on Animal Use at the University of Utah.

Experimental design. Studies began 3-7 d after surgery, when the fetuses were healthy, as assessed by arterial $\mathrm{pH}$ and blood gas tensions, and lung lymph was free of visible blood. We studied the lambs for a 2- to 4-h baseline period before birth and for $8 \mathrm{~h}$ after birth. During the study, we continuously measured systemic and pulmonary vascular pressures, as well as pleural, amniotic (before birth), and airway (after birth) pressures. We collected lung lymph every $30 \mathrm{~min}$ and aspirated fluid from each pleural space every 5-10 min. We collected samples of blood hourly for measurement of hematocrit, $\mathrm{pH}$, $\mathrm{PO}_{2}, \mathrm{PCO}_{2}$, and plasma protein concentration.

During the prenatal portion of each study, the ewe stood unrestrained with free access to food and water. After a minimum of $2 \mathrm{~h}$ of steady state measurements, defined as less than a $10 \%$ variation from the mean for lymph flow and vascular pressures, we gave the ewe spinal anesthesia with 2 $\mathrm{mL}$ of $1 \%$ tetracaine in preparation for abdominal delivery of the fetus. After incising the abdomen and uterus, we exposed the fetal head and sutured a $4.0-\mathrm{mm}$ plastic endotracheal tube into the trachea; we also placed a small polyvinyl catheter (1.27 $\mathrm{mm}$ inside diameter) into the trachea for measurement of airway pressure, through which we instilled $10 \mathrm{~mL}$ of either saline $(n=8)$ or calf lung surfactant $(n=4$; Infasurf, a generous gift from ONY, Inc., Amherst, NY). We then ligated the umbilical cord, delivered the lamb, weighed it, and placed it under a radiant heater to keep its body temperature at $37-39^{\circ} \mathrm{C}$, which is the normal range for newborn lambs.

We mechanically ventilated the lamb with a time-cycled, pressure-limited infant ventilator (Sechrist Ventilators, Anaheim, CA). The ventilator rate was 30 breaths $/ \mathrm{min}$, and the inspiratory time was $0.5 \mathrm{~s}$. The lambs breathed $100 \% \mathrm{O}_{2}$ that was humidified and warmed to $34-36^{\circ} \mathrm{C}$. The peak inspiratory pressure was initially set at $2.9 \mathrm{kPa}\left(30 \mathrm{~cm} \mathrm{H}_{2} \mathrm{O}\right)$ and subsequently adjusted to maintain $\mathrm{PCO}_{2}$ at $4.7-6.0 \mathrm{kPa}(35-45 \mathrm{~mm}$ $\mathrm{Hg}$ ). End expiratory pressure was kept at $0.4-0.6 \mathrm{kPa}(4-6 \mathrm{~cm}$ $\mathrm{H}_{2} \mathrm{O}$ ), and the gas flow rate was set at $12 \mathrm{~L} / \mathrm{min}$. We administered buprenorphine (Reckitt \& Colman Pharmaceuticals, Richmond, VA), $0.1 \mathrm{mg} / \mathrm{kg}$ i.v., and pancuronium (Organon Inc., West Orange, NJ), $0.1 \mathrm{mg} / \mathrm{kg}$ i.v., soon after birth to prevent agitation and facilitate mechanical ventilation. During the study we intravenously infused a glucose-electrolyte solution $\left(2.5-5 \%\right.$ glucose, $75 \mathrm{mEq} / \mathrm{L} \mathrm{NaCl}$, and $\left.25 \mathrm{mEq} / \mathrm{L} \mathrm{HCO}_{3}\right)$ at $10 \mathrm{~mL} / \mathrm{kg}$ body weight, a rate that we previously found necessary to maintain hemodynamic stability and prevent dehydration (1).

We made vascular and thoracic pressure measurements using calibrated transducers (Statham Instruments, Oxnard, CA) that were connected to a recording instrument (Grass Instruments, Quincy, MA). We used amniotic pressure as a reference for vascular pressures before birth and atmospheric pressure as a reference for vascular, airway, and pleural pressures after birth. Postnatally, vascular pressures were measured relative to the height of the left atrium. All catheters were flushed intermittently with saline containing heparin $(10 \mathrm{U} / \mathrm{mL})$.

Postmortem studies. We intravenously injected pentobarbital ( $30 \mathrm{mg} / \mathrm{kg}$ body weight) into the lamb $8 \mathrm{~h}$ after birth, rapidly split the sternum, aspirated blood from the heart, and clamped the hili at the prevailing peak inflation pressure. We placed samples of inflated lung in liquid nitrogen and $10 \%$ formalin solution for subsequent microscopy, and we homogenized the remaining tissue for measurement of blood and extravascular water content by a modification (16) of the method described by Pearce et al. (17).

Analytical methods. We centrifuged samples of blood, lymph, and pleural liquid, and measured the concentration of total protein and albumin in the supernatant liquids (Clinical System 700, Beckman Instruments, Fullerton, CA). We used a blood gas analyzer (model 158, Ciba Corning, Medfield, MA) to measure the $\mathrm{pH}$ and $\mathrm{Po}_{2}$ and $\mathrm{PCO}_{2}$ in samples of arterial blood.

Statistical analysis. Results in the text and tables are expressed as mean \pm 1 SEM. When comparing average values of liquid samples taken before birth with those obtained $6-8 \mathrm{~h}$ after birth, we used a paired $t$ test or the Wilcoxon rank test. When comparing sample means for similar time periods between the two groups of lambs, we used an unpaired $t$ test or the Mann-Whitney test. When we analyzed the relationship of 
one variable to another, we used simple linear regression. We considered a difference significant if $p$ was $<0.05$. Statistical analysis was done using a commercially available computer program (StatView SE+ Graphics, Abacus Concepts Inc., Berkeley, CA) and standard statistical tables (18).

\section{RESULTS}

The two groups of lambs (control and surfactant-treated) were similar in age and size before birth. Gestational age averaged $128 \pm 0.2 \mathrm{~d}$ in control lambs (range, 127-128 d) and $128 \pm 0.3 \mathrm{~d}$ in lambs treated with surfactant (range, 127-128 d); control lambs weighed $3.2 \pm 0.2 \mathrm{~kg}$, and lambs treated with surfactant weighed $3.2 \pm 0.1 \mathrm{~kg}$.

Physiologic variables did not differ between control and surfactant-treated lambs before birth (Table 1). During the 6-8 $\mathrm{h}$ after birth, aortic pressure increased to the same degree in both groups, and pulmonary arterial pressure remained elevated in both control and surfactant-treated lambs, although postnatally, pulmonary arterial pressure tended to increase in control lambs and either decreased or remained the same in surfactant-treated lambs. During the $6-8 \mathrm{~h}$ after birth, $\mathrm{Po}_{2}$ increased significantly in surfactant-treated lambs, but it did not change from prenatal values in control lambs; seven of the eight control lambs had severe hypoxemia $6-8 \mathrm{~h}$ after birth, defined as a $\mathrm{Po}_{2}$ of less than $6.7 \mathrm{kPa}(50 \mathrm{~mm} \mathrm{Hg})$ in $100 \% \mathrm{O}_{2}$, whereas none of the surfactant-treated lambs had a $\mathrm{Po}_{2}$ less than $6.7 \mathrm{kPa}$.

Control lambs required significantly greater peak inflation pressure at $0-2 \mathrm{~h}$ and $6-8 \mathrm{~h}$ after birth compared with lambs treated with surfactant (Table 2). Mean airway pressure during these two time periods was also significantly different. End

Table 1. Physiologic variables $2-4 h$ before and 6-8 $h$ after birth in preterm lambs treated at birth with either placebo (control) or surfactant (surfactant-treated)

\begin{tabular}{|c|c|c|c|c|}
\hline & \multicolumn{2}{|c|}{ Control } & \multicolumn{2}{|c|}{ Surfactant-treated } \\
\hline & Before birth & After birth & Before birth & After birth \\
\hline Heart rate (beats/min) & $181 \pm 6$ & $188 \pm 10$ & $179 \pm 4$ & $210 \pm 13$ \\
\hline \multicolumn{5}{|l|}{$\begin{array}{l}\text { Vascular pressures } \\
\qquad(\mathrm{kPa})\end{array}$} \\
\hline Aorta & $5.9 \pm 0.1$ & $7.5 \pm 0.3^{*}$ & $5.6 \pm 0.3$ & $7.2 \pm 0.4^{*}$ \\
\hline Pulmonary artery & $6.1 \pm 0.1$ & $7.2 \pm 0.6$ & $6.0 \pm 0.3$ & $5.6 \pm 0.4$ \\
\hline Left atrium & $0.2 \pm 0.1$ & $0.4 \pm 0.1^{*}$ & $0.1 \pm 0.1$ & $0.5 \pm 0.1$ \\
\hline \multicolumn{5}{|l|}{$\begin{array}{l}\text { Protein concentration } \\
\qquad(\mathrm{g} / \mathrm{dL})\end{array}$} \\
\hline Lymph protein & $2.6 \pm 0.1$ & $1.5 \pm 0.1^{*}$ & $2.4 \pm 0.1$ & $1.5 \pm 0.1^{*}$ \\
\hline Pleural protein & $2.0 \pm 0.1$ & $1.7 \pm 0.1$ & $2.3 \pm 0.1$ & $1.8 \pm 0.2$ \\
\hline Plasma protein & $3.3 \pm 0.1$ & $2.5 \pm 0.2^{*}$ & $3.1 \pm 0.1$ & $3.0 \pm 0.2$ \\
\hline \multicolumn{5}{|l|}{ Blood values } \\
\hline $\mathrm{pH}$ & $7.38 \pm 0.01$ & $7.25 \pm 0.05^{*}$ & $7.34 \pm 0.03$ & $7.38 \pm 0.03$ \\
\hline Arterial $\mathrm{Po}_{2}(\mathrm{kPa})$ & $2.7 \pm 0.1$ & $4.8 \pm 1.3$ & $2.8 \pm 0.1$ & $37 \pm 7^{*}$ \\
\hline Arterial $\mathrm{PCO}_{2}(\mathrm{kPa})$ & $6.2 \pm 0.1$ & $6.5 \pm 0.6$ & $5.9 \pm 0.2$ & $5.3 \pm 0.2$ \\
\hline Hematocrit $(\%)$ & $35 \pm 1$ & $39 \pm 2^{*}$ & $34 \pm 1$ & $37 \pm 2$ \\
\hline
\end{tabular}

Before birth and after birth refer to 2-4 h before and 6-8 h after birth, respectively. Control lambs, $n=8$; surfactant-treated lambs, $n=4$.

* Significantly different from before birth; $p<0.05$.
Table 2. Intrathoracic pressures $0-2 h$ after and 6-8 $h$ after birth in preterm lambs treated at birth with either placebo (control) or surfactant (surfactant-treated)

\begin{tabular}{llllll}
\hline \multirow{2}{*}{$\begin{array}{c}\text { Intrathoracic pressures } \\
(\mathrm{kPa})\end{array}$} & \multicolumn{2}{c}{ Control } & & \multicolumn{2}{c}{ Surfactant-treated } \\
\cline { 2 - 3 } \cline { 5 - 6 } & $0-2 \mathrm{~h}$ & $6-8 \mathrm{~h}$ & & $0-2 \mathrm{~h}$ & $6-8 \mathrm{~h}$ \\
\hline Peak inspiratory & $4.2 \pm 0.2$ & $4.8 \pm 0.4$ & & $2.6 \pm 0.2^{*}$ & $2.3 \pm 0.4^{*}$ \\
End expiratory & $0.5 \pm 0.01$ & $0.5 \pm 0.1$ & & $0.5 \pm 0.001$ & $0.5 \pm 0.02$ \\
Mean airway & $1.3 \pm 0.05$ & $1.4 \pm 0.1$ & & $0.9 \pm 0.02^{*}$ & $0.8 \pm 0.1^{*}$ \\
Pleural & $0.3 \pm 0.1$ & $0.2 \pm 0.1$ & & $0.1 \pm 0.1$ & $0.2 \pm 0.2$ \\
\hline
\end{tabular}

Zero to $2 \mathrm{~h}$ and $6-8 \mathrm{~h}$ refer hours after birth. Control lambs, $n=8$; surfactant-treated lambs, $n=4$.

* Significantly different from corresponding time period in control lambs; $p$ $<0.05$.

expiratory pressure and mean pleural pressure were similar between the two groups of lambs during both time periods.

Lymph, pleural liquid, and plasma protein concentrations were similar before birth in the two groups of lambs. The L/P averaged $0.77 \pm 0.02$ in control lambs and $0.78 \pm 0.01$ in surfactant-treated lambs before birth. During the first $2 \mathrm{~h}$ after birth, lymph protein concentration decreased on average to 1.7 $\pm 0.1 \mathrm{~g} / \mathrm{dL}$ (average decrease, $32 \pm 4 \%$ from before birth) in control lambs and to $2.0 \pm 0.1 \mathrm{~g} / \mathrm{dL}$ (average decrease, $17 \pm$ $4 \%$ from before birth) in surfactant-treated lambs. Plasma protein concentration during this time averaged $3.3 \pm 0.1 \mathrm{~g} / \mathrm{dL}$ ( $2 \pm 2 \%$ reduction from before birth) in control lambs and 3.4 $\pm 0.1 \mathrm{~g} / \mathrm{dL}(10 \pm 3 \%$ increase from before birth $)$ in surfactanttreated lambs.

During the final $2 \mathrm{~h}$ of study, protein concentration in lymph fell to the same degree in control and surfactant-treated lambs. During this time, the protein concentration in plasma had decreased further from prenatal values in control lambs compared with surfactant-treated lambs $(24 \pm 5 \%$ versus $2 \pm 4 \%$, respectively). L/P decreased in both groups by $6-8 \mathrm{~h}$ after birth, but the decrease was greater in surfactant-treated lambs compared with control lambs (control, $0.61 \pm 0.03$; surfactanttreated, $0.50 \pm 0.02$ ). The lower $\mathrm{L} / \mathrm{P}$ in both groups after birth compared with before birth probably reflects the low protein concentration of liquid that drained from the lung lumen into the interstitium $(1,13)$, with subsequent removal by way of the pulmonary circulation or lymphatics.

By $6-8 \mathrm{~h}$ after birth, total lung liquid drainage (the sum of lymph and pleural liquid values) increased significantly by an average of $334 \pm 117 \%$ over prenatal values in control lambs, but it did not change significantly after birth in surfactanttreated lambs (Table 3). Total protein drainage at $6-8 \mathrm{~h}$ after birth more than doubled in control lambs (average increase after birth, $174 \pm 66 \%$ ), whereas protein drainage either remained the same or decreased in lambs that were treated with surfactant. We calculated the total amount of protein drained from the lung lymph and pleural spaces during the entire $8 \mathrm{~h}$ after birth, corrected for the rate of drainage $2-4 \mathrm{~h}$ before birth. This excess protein drainage after birth in control lambs was nearly four times that drained from surfactant-treated lambs (control, $677 \pm 185 \mathrm{mg}$ versus surfactant-treated, $177 \pm 79$ $\mathrm{mg} ; p=0.06$ ).

Extravascular lung water was significantly less after surfactant treatment (control, $6.5 \pm 0.3$ versus surfactant-treated, 5.0 
Table 3. Liquid flow and protein drainage data from preterm lambs treated with placebo or surfactant at birth

\begin{tabular}{|c|c|c|c|c|c|c|c|}
\hline \multirow[b]{2}{*}{ Treatment group } & \multirow[b]{2}{*}{ Time period } & \multicolumn{3}{|c|}{ Fluid flow rates $(\mathrm{mL} / \mathrm{h})$} & \multicolumn{3}{|c|}{ Protein flow rates $(\mathrm{mg} / \mathrm{h})$} \\
\hline & & Lymph & Pleural & Total & Lymph & Pleural & Total \\
\hline \multirow[t]{2}{*}{ Control } & Before birth & $1.5 \pm 0.3$ & $1.1 \pm 0.6$ & $2.7 \pm 0.4$ & $39 \pm 7$ & $19 \pm 8$ & $58 \pm 7$ \\
\hline & After birth & $4.1 \pm 1.1^{*}$ & $5.1 \pm 1.7$ & $9.2 \pm 2.1^{*}$ & $58 \pm 14$ & $76 \pm 21^{*}$ & $134 \pm 25^{*}$ \\
\hline \multirow[t]{2}{*}{ Surfactant-treated } & Before birth & $2.1 \pm 0.2$ & $0.2 \pm 0.2$ & $2.3 \pm 0.3$ & $50 \pm 3$ & $5 \pm 3$ & $54 \pm 6$ \\
\hline & After birth & $2.7 \pm 0.7$ & $0.7 \pm 0.3$ & $3.4 \pm 0.9$ & $38 \pm 6$ & $12 \pm 5$ & $50 \pm 8$ \\
\hline
\end{tabular}

Control lambs, $n=8$; surfactant-treated lambs, $n=4$. Before and after birth refer to $2-4 \mathrm{~h}$ before and $6-8 \mathrm{~h}$ after birth.

* Significantly different from before birth; $p<0.05$.

$\pm 0.2 \mathrm{~g} / \mathrm{g}$ dry lung). The reduction in lung water seen in the lambs treated with surfactant was not a result of dehydration; postmortem body weight was similar in both groups of lambs (control, $3.1 \pm 0.2 \mathrm{~kg}$ versus surfactant-treated, $3.0 \pm 0.1 \mathrm{~kg}$ ). There was a close correlation between extravascular lung water and peak inflation pressure both at $0-2$ and $6-8 \mathrm{~h}$ after birth $(r$ $=0.81,0-2 \mathrm{~h} ; r=0.92,6-8 \mathrm{~h}$; Fig. 1). Both total lung liquid and protein drainage correlated directly with peak inflation pressure at $6-8 \mathrm{~h}\left(r=0.69\right.$ for both, data not shown). $\mathrm{Po}_{2}$ at $6-8 \mathrm{~h}$ was inversely related to extravascular lung water $(r=$ 0.82 , data not shown).

Postmortem examination showed scattered areas of collapse in the lungs of control lambs, whereas lambs treated with surfactant had well-inflated lungs and only minimal atelectasis. Light microscopy of lung tissue showed extensive atelectasis, hyaline membranes, edema, and air space hypercellularity in control lambs, features that were not present in surfactanttreated lambs (Fig. 2).
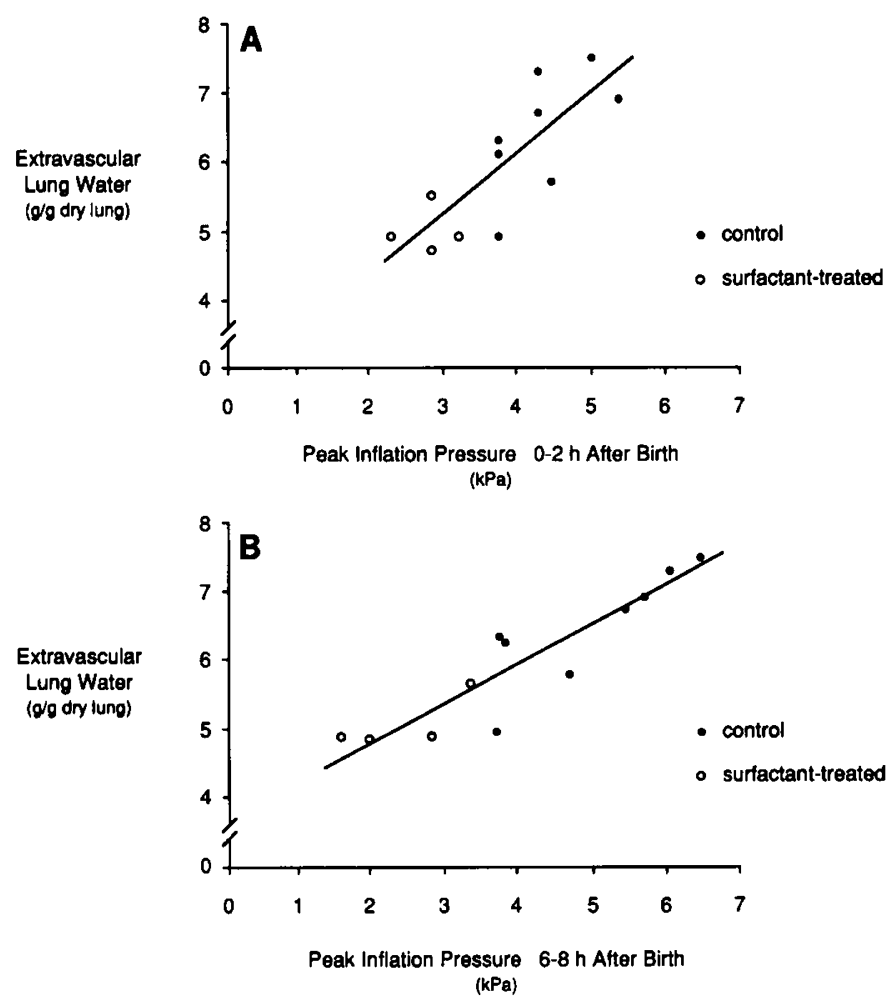

Figure 1. Relationship between peak inflation pressure and extravasulcar lung water content at postmortem in preterm lambs treated with either saline placebo (closed circles) or surfactant (open circles) at the time of delivery. A, Zero to $2 \mathrm{~h}$ after birth; $B, 6-8 \mathrm{~h}$ after birth.

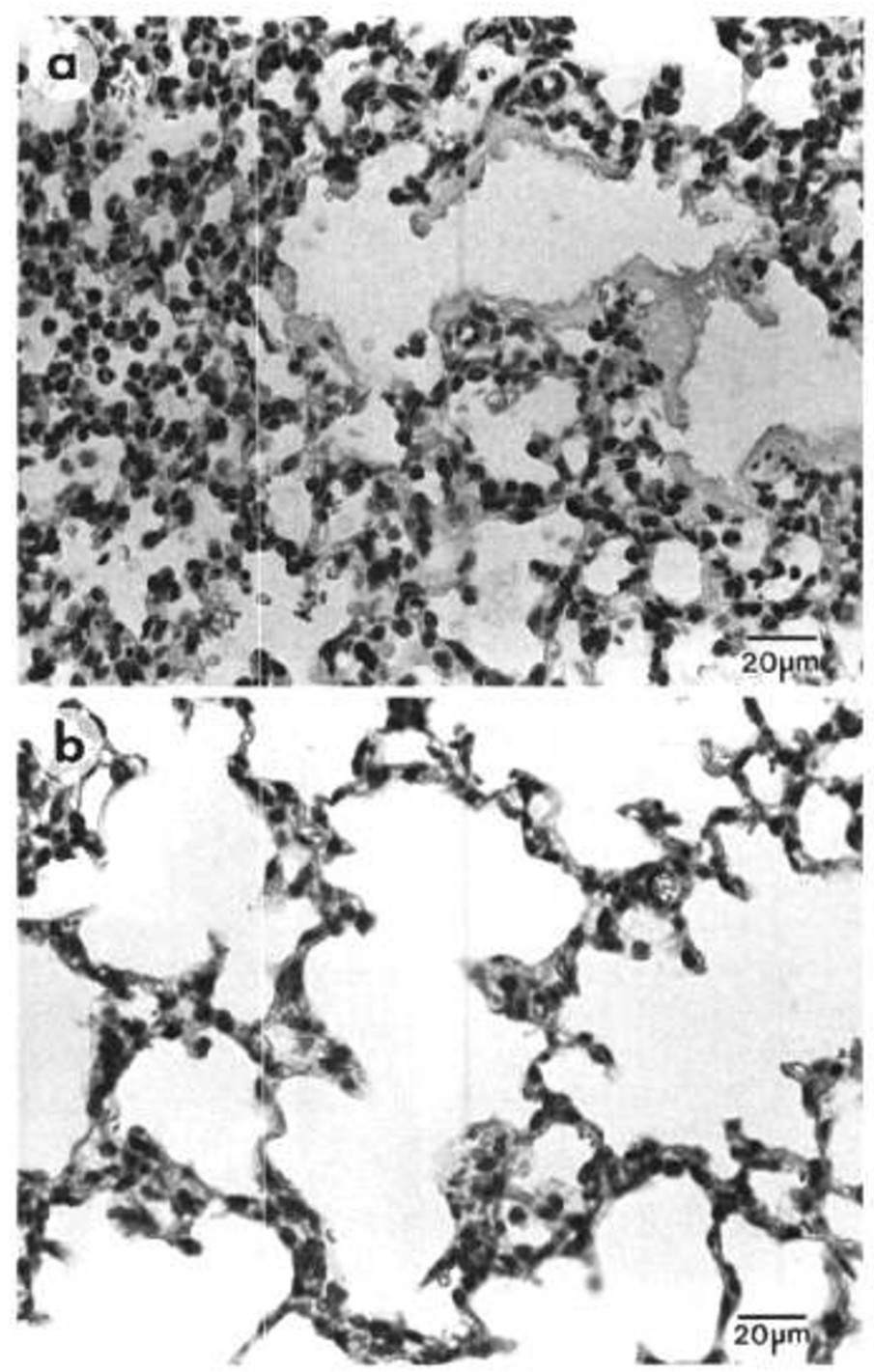

Figure 2. Photomicrographs of sections of lung tissue from preterm lambs treated with saline placebo $(a)$ and surfactant $(b)$ at time time of delivery. Tissue sections are stained with hematoxylin and eosin. Both photomicrographs are the same magnification (see scale bar).

\section{DISCUSSION}

Pulmonary edema often accompanies the respiratory distress syndrome that occurs after premature birth (1-3). Surfactant treatment theoretically should reduce lung edema $(7,8)$, but previous studies did not detect an effect of surfactant on lung water accumulation after premature birth, perhaps because of the short duration of the studies $(2-3 \mathrm{~h}$ after birth) $(10,11)$. Our studies, which lasted $8 \mathrm{~h}$ after birth, demonstrate that surfactant 
administration at the time of delivery inhibits the postnatal increase in transvascular fluid and protein movement that occurs after premature birth, and that this effect is associated with less pulmonary edema.

The chronic lung lymph fistula preparation that we used provides a useful means of assessing vascular fluid and protein leak before and after birth $(1,19,20)$. We assessed net liquid and protein fluxes across the pulmonary microcirculation by using lung lymph and pleural liquid flow as indexes of transvascular fluid movement. We included measurements of fluid leaving the lung through the pleural spaces, because we and others have demonstrated that the pleural space is an important pathway for drainage of liquid and protein from edematous lungs $(1,21,22)$. In this study, as well as in our previous study of respiratory distress after premature birth (1), we found that drainage of liquid through the pleural space contributes substantially to net clearance of liquid from the lungs.

One reason for less pulmonary edema in the surfactanttreated lambs is the reduction in transvascular movement of fluid from the pulmonary circulation into the lung. Lymph and pleural liquid clearance increased significantly after birth in control lambs but not in surfactant-treated lambs. In addition, lymph and pleural liquid protein drainage increased significantly, by an average of approximately $175 \%$ in control lambs 6-8 $\mathrm{h}$ after birth, but protein drainage decreased on average by approximately $4 \%$ 6-8 $\mathrm{h}$ after birth in surfactant-treated lambs. Moreover, the $\mathrm{L} / \mathrm{P}$ ratio during the final $2 \mathrm{~h}$ of study was significantly greater in control lambs than in those lambs that received surfactant. The differences in liquid clearance, protein drainage, and $\mathrm{L} / \mathrm{P}$ ratio between control and surfactant-treated lambs are indicative of a difference in vascular protein permeability between the groups $(1,23,24)$.

Our observation that surfactant inhibits changes in lung vascular integrity after birth complements the work of previous investigators who demonstrated the importance of surfactant in maintaining alveolar epithelial integrity after birth. Jobe et al. (25) showed that alveolar epithelial protein leak was greater after birth in immature, surfactant-deficient lambs than in term lambs, and that surfactant replacement decreased the postnatal protein leak (26). Robertson et al. (27) showed a similar effect of surfactant on alveolar epithelial protein permeability in premature rabbit lungs. Thus, the presence of adequate surfactant in the air spaces after birth helps preserve the barrier function of both the pulmonary epithelium and endothelium.

Although an increase in lung vascular protein permeability contributed to the observed changes in lymph and pleural liquid flow after birth, it is also likely that hydrostatic forces for fluid filtration were influenced by surfactant replacement. Pattle (8) and Clements (7) suggested that without surfactant, the surface tension of the fluid lining the alveolar surface would be increased and result in a lower liquid pressure in the alveolar subphase. The lower subphase pressure would be expected to reduce interstitial pressure and thereby promote transvascular filtration of liquid from the microcirculation into the lung (7). Experiments in in situ lungs from adult dogs and direct micropuncture experiments with isolated lungs from fetal rabbits confirmed this hypothesis $(9,28)$. In experiments with fetal rabbit lungs, Raj (9) found that alveolar liquid pressure was lower in immature lungs that contained small amounts of alveolar-space phospholipid than in mature lungs with greater amounts of alveolar-space phospholipid; surfactant replacement in immature lungs increased alveolar liquid pressure. Because preterm lambs of the gestational age used in our study are surfactant-deficient (29), interstitial pressure was probably lower in the control lambs than in the surfactanttreated lambs, thereby augmenting the driving force for transvascular filtration of liquid from the microcirculation and contributing to the increase in lymph and pleural liquid flow that occurred after birth in the control lambs.

In addition to its effect on lung interstitial pressure, surfactant administration inhibited the reduction in plasma protein osmotic pressure that occurred in control lambs. Although lymph protein concentration was similar between the two groups during the $6-8 \mathrm{~h}$ after birth, plasma protein concentration decreased further from prenatal values in control lambs than in surfactant-treated lambs. This relative systemic hypoproteinemia in the control lambs was not present in the surfactant-treated lambs, and the greater plasma protein concentration should have contributed to less filtration of fluid into the interstitium (30). The changes in plasma protein concentration and hematocrit in control lambs are similar to those in our previous study of respiratory distress in premature lambs after birth (1). These changes are most consistent with loss of plasma proteins into the interstitium and concomitant concentration of circulating red cell mass.

Previous studies showed that lung vascular filtration pressure, and in particular, protein osmotic pressure, may influence the rate of clearance of alveolar liquid from the lungs of newborn lambs $(31,32)$. Thus, it is likely that differences in plasma protein concentration and net transvascular filtration pressure in the lungs of surfactant-treated versus control lambs may have contributed to the observed differences in lung water content between the two groups of animals.

Besides reducing fluid filtration into the lung interstitium, is it possible that surfactant administration might affect the rate of clearance of fetal lung liquid that is present in the distal air spaces at birth? Egan et al. (33) showed that clearance of fetal lung liquid from the lung lumen into the interstitium was faster in premature, surfactant-deficient lambs than in mature lambs, although total lung water remained abnormally high, implying that clearance of liquid from the interstitium was impaired. We did not measure alveolar liquid volume in our studies, but our observation that lymph protein concentration fell to a greater extent soon after birth in control lambs than in surfactanttreated lambs is consistent with the notion that surfactant does not accelerate the shift of liquid from the lung lumen into the interstitium. We cannot, however, exclude the possibility that more favorable filtration forces in the lungs of surfactanttreated lambs may have contributed to more rapid clearance of fetal lung liquid into the circulation.

The mechanism by which surfactant treatment at birth prevents an increase in lung vascular protein permeability is unclear. Previous studies have shown that high lung inflation pressure coupled with large inflation volume damages the pulmonary microcirculation $(23,34,35)$. In these studies, the investigators purposefully overinfiated normal lungs to dem- 
onstrate the effect of inflation volume on vascular permeability. In our study, we found that lung vascular protein leak and edema were directly related to inflation pressure soon after birth, but unlike previous studies examining this issue, we did not intentionally overinflate the lungs. We speculate, however, that the pulmonary microcirculation may be more susceptible to inflation injury in the premature lung than in the mature lung, and that measures designed to prevent overdistension of air spaces might also inhibit changes in lung vascular protein permeability and resultant pulmonary edema.

Acknowledgments. The authors thank Jason Miciak for his technical assistance and S. Marron for preparing the manuscript. The authors also would like to thank Kurt H. Albertine, Ph.D., and Nancy Chandler of the Research Microscopy Center at the University of Utah for their microscopy assistance.

\section{REFERENCES}

1. Bland RD, Carlton DP, Scheerer RG, Cummings JJ, Chapman DL 1989 Lung fluid balance in lambs before and after premature birth. J Clin Invest 84:568-576

2. DeSa DJ 1969 Pulmonary fluid content in infants with respiratory distress. J Pathol 97:469-479

3. Sundell HW, Harris TR, Cannon JR, Lindstrom DP, Green R, Rojas J, Brigham KL 1987 Lung water and vascular permeability-surface area in premature newborn lambs with hyaline membrane disease. Circ Res 60:923-932

4. Jobe AH 1993 Pulmonary surfactant therapy. N Engl J Med 328:861-868

5. Kwong MS, Egan EA, Notter RH, Shapiro DL 1985 Double-blind clinical trial of calf lung surfactant extract for the prevention of hyaline membrane disease in extremely premature infants. Pediatrics 76:585-592

6. Enhorning G, Shennan A, Possmayer F, Dunn M, Chen CP, Milligan J 1985 Prevention of neonatal respiratory distress syndrome of tracheal instillation of surfactant: a randomized clinical trial. Pediatrics 76:145-153

7. Clements JA 1961 Pulmonary edema and permeability of alveolar membranes. Arch Environ Health 2:280-283

8. Pattle RE 1958 Properties, function and origin of the alveolar lining layer. Proc R Soc Lond [Biol] 148:217-240

9. Raj JU 1987 Alveolar liquid pressure measured by micropuncture in isolated lungs of mature and immature fetal rabbits. J Clin Invest 79:1579-1588

10. Adams FH, Towers B, Osher AB, Ikegami M, Fujiwara T, Nozaki M 1978 Effects of tracheal instillation of natural surfactant in premature lambs. I. Clinical autopsy findings. Pediatr Res 12:841-848

11. Derechin NM, Schlueter MA, Brown CL, Tooley WH, Clements JA, Bland RD 1984 Controlled trial of a protein-free synthetic surfactant in preterm rabbbits. Pediatr Res 18:387A(abstr)

12. Notter RH, Egan EA, Kwong MS, Holm BA, Shapiro DL 1985 Lung surfactant replacement in premature lambs with extracted lipids from bovine lung lavage: effects of dose, dispersion technique, and gestational age. Pediatr Res 19:569-577

13. Bland RD, Hansen TN, Haberkern CM, Bressack MA, Hazinski TA, Raj JU, Goldberg RB 1982 Lung fluid balance in lambs before and after birth. J Appl Physiol 53:992-1004
14. Humphreys PW, Normand ICS, Reynolds EOR, Strang LB 1967 Pulmonary lymph flow and the uptake of liquid from the lungs of the lamb at the start of breathing. $J$ Physiol (Lond) 193:1-29

15. Chanana AD, Joel IDD 1986 Contamination of lung lymph following standard and modified procedures in sheep. J Appl Physiol 60:809-816

16. Erdmann III AJ, Vaughan TR Jr, Brigham KL, Woolverton WC, Staub NC 1975 Effect of increased vascular pressure on lung fluid balance in unanesthetized sheep. Circ Res 37:271-28:5

17. Pearce ML, Yamashita J, Beazell J 1965 Measurement of pulmonary edema. Circ Res $16: 482-488$

18. Zar JH 1974 Biostatistical Analysis. Prentice-Hall, Englewood Cliffs, NJ, pp 563-564

19. Bland RD, McMillar. DD 1977 Lung fluid dynamics in awake newborn lambs. J Clin Invest 60:1107-1115

20. Carlton DP, Cummings JJ, Poulain FR, Bland RD 1992 Increased pulmonary vascular filtration pressure does not alter lung liquid secretion in fetal sheep. J Appl Physiol 72:650-655

21. Broaddus VC, Wiene:-Kronish JP, Staub NC 1990 Clearance of lung edema into the pleural space of volume-loaded anesthetized sheep. J Appl Physiol 68:2623-2630

22. Weiner-Kronish J, Broaddus V, Albertine K, Gropper M, Matthay M, Staub N 1988 Relationship of pleural effusions to increased permeability pulmonary edema in anesthetized sheep. J Clin Invest 82:1422-1429

23. Carlton DP, Cummings JJ, Scheerer RG, Poulain FR, Bland RD 1990 Lung overexpansion increases pulmonary microvascular protein permeability in young lambs. $J$ Appl Physiol 69:577--583

24. Bressack MA, McMillan DD, Bland RD 1979 Pulmonary oxygen toxicity: increased microvascular permeability to protein in unanesthetized lambs. Lymphology 12:133139

25. Jobe A, Ikegami M, Jackobs H, Jones S, Conaway D. 1983 Permeability of premature lamb lungs to protein and the effect of surfactant on that permeability. J Appl Physiol 55:169-176

26. Jobe A, Jacobs H, Ikegami M, Berry D 1985 Lung protein leaks in ventilated lambs: effect of gestational z.ge. J Appl Physiol 58:1246-1251

27. Robertson B, Berry D, Curstedt T, Grossmann G, Ikegami M, Jacobs H, Jobe A, Jones S 1985 Leakage of protein in the immature rabbit lung: effect of surfactant replacement. Respir Physiol 61:265-276

28. Albert RK, Lakshminarayan S, Hildebrandt J, Kirk W 1979 Increased surface tension favors pulmonary edema formation in anesthetized dogs' lungs. J Clin Invest 63:1015-1018

29. Cummings JJ, Holm BA, Hudak ML, Hudak BB, Ferguson WH, Egan EA 1992 A controlled clinical comparison of four different surfactant preparations in surfactantdeficient preterm lambs. Am Rev Respir Dis 145:999-1004

30. Hazinski TA, Bland RD, Hansen TN, Sedin EG, Goldberg RB 1986 Effect of hypoproteinemia on lung fluid balance in awake newborn lambs. J Appl Physiol 61:1139-1148

31. Raj JU, Bland RD 1986 Lung luminal liquid clearance in newborn lambs. Am Rev Respir Dis 134:305-\$10

32. Cummings JJ, Carlton DP, Poulain FR, Raj JU, Bland RD 1993 Hypoproteinemia slows lung liquid clearance in young lambs. J Appl Physiol 74:153-160

33. Egan EA, Dillon WP, Zorn S 1984 Fetal lung liquid absorption and alveolar epithelial solute permeability in surfactant deficient, breathing fetal lambs. Pediatr Res 18:566570

34. Dreyfuss D, Soler P, Basset G, Saumon G 1988 High inflation pressure pulmonary edema. Respective effects of high airway pressure, high tidal volume, and positive end-expiratory pressure. Am Rev Respir Dis 137:1159-1164

35. Hernandez LA, Peevy KJ, Moise AA, Parker JC 1989 Chest wall restriction limits high airway pressure-induced lung injury in young rabbits. J App! Physiol 66:23642368 